\title{
IMPLEMENTASI ALGORITMA BACKGROUND SUBTRACTION UNTUK DETEKSI TINGGI MUKA AIR (TMA) PADA APLIKASI PERINGATAN DINI BANJIR BANDANG BERBASIS PENGOLAHAN CITRA
}

\author{
Rio Priantama \\ Teknik Informatika \\ Universitas Kuningan \\ Email: rio.priantama@uniku.ac.id
}

\begin{abstract}
Abstrak
Banjir merupakan fenomena yang hampir selalu terjadi setiap tahun di berbagai daerah di seluruh Indonesia dengan bermacam variasi siklus. Pada musim hujan, tingginya curah hujan yang dan daerah aliran sungai yang menyempit dan terjadi pendangkalan, tidak lagi mampu menampung aliran air sehingga terjadi banjir bandang. Mekanisme peringatan banjir berjalan dengan kearifan lokal secara tradisional yang sangat bergantung pada ketersediaan dan kemampuan cepat tanggap dari personal yang ditugaskan mengawasi sungai. Oleh karena itu inovasi pengembangan dari sistem yang ada diharapkan mampu memberikan informasi dan data secara berkala dan menjadi peringatan lebih awal terhadap banjir bandang guna meminimalisir dampak.Pengolahan citra dapat dimanfaatkan sebagai dasar inovasi dari mekanisme peringatan banjir yang ada. Metode Background Substraction dilakukan untuk mendeteksi secara otomatis Tinggi Muka Air (TMA) pada papan kontrol (Peil) melalui IP Camera yang menjadi parameter input bagi sistem dan diolah menjadi informasi bagi pihak berkepentingan. Deteksi level ketinggian air / TMA berdasarkan penunjukan warna merah pada papan kontrol (Peil) dengan background subtraction, dilakukan pada skala nyata, yang dikembagkan dari penelitian-penelitian sebelumnya. Pengujian dilakukan terhadap proses pendeteksian level ketinggian air yang meliputi jarak jangkauan IP kamera dan sudut dan juga posisi ketinggian IP kamera dengan intensitas cahaya.Hasil analisis deteksi Tinggi Muka Air (TMA) pada papan peil berupa jarak jangkauan dan sudut IP kamera dalam mendeteksi dan melacak level TMA yaitu optimal pada jarak 200 - $600 \mathrm{~cm}$ dengan sudut 30, 45, dan 60 derajat, skala TMA Peil dapat terdeteksi dan dapat dianalisis. Pada parameter posisi ketinggian IP kamera dengan intensitas cahaya, hasil analisis menunjukan bahwa ketinggian posisi IP Kamera dari 1150 - $1250 \mathrm{~cm}$ dengn intensitas cahaya antara 786 - 1980 lux,optimal dalam menangkap area Skala TMA Peil agar terdeteksi
\end{abstract}

Kata Kunci: Banjir Bandang, Pengolahan Citra, Backgroun Subtraction, Level Tinggi Muka $\operatorname{Air}(T M A)$.

\footnotetext{
Abstract

Flooding is a phenomenon that almost always occurs every year in various regions throughout Indonesia with a variety of cycle variations. In the rainy season, high rainfall and narrowed watersheds and silting up are no longer able to accommodate the flow of water, causing flash floods. The flood warning mechanism operates with traditional local wisdom that is highly dependent on the availability and responsiveness of the personnel assigned to oversee the river. Therefore the innovation development of the existing system is expected to be able to provide information and data on a regular basis and be an early warning to flash floods to minimize impacts.Image processing can be used as a basis for innovation from existing flood warning mechanisms. The Background Substraction method is carried out to automatically detect High Levels of Water (TMA) on the control board (Peil) via an IP Camera which is an input parameter for the system and is processed into information for interested parties. Detection of water level / TMA based on the designation of red on the control board (Peil) with
} 
background subtraction, carried out on a real scale, developed from previous studies. Tests carried out on the process of detecting the level of water level which includes the distance range of the camera's IP and angle and also the position of the IP camera's height with light intensity. The results of analysis of detection of water level (TMA) on the peil board in the form of the range and angle of the IP camera in detecting and tracking the level of the TMA is optimal at a distance of 200-600 cm with angles of 30, 45, and 60 degrees, the TMA Peil scale can be detected and can be analyzed. In the parameters of the IP camera's height position with light intensity, the results of the analysis show that the IP camera's height position from 1150-1250 cm with light intensity between 786 - 1980 lux, optimal in capturing the Peil TMA Scale area to be detected

Keywords: Flash Floods, Image Processing, Background Subtraction, High Level Water Face (TMA)

\section{PENDAHULUAN}

Curah hujan tinggi pada saat musim hujan dan melalui daerah aliran sungai (DAS) yang menyempit dan terjadi pendangkalan, sementara vegetasi penahan air di daerah hulu semakin berkurang, maka dapat meneybabkan terjadinya banjir bandang. Kerusakan fisik dan psikologis yang ada akibat bajir bandang menimbulkan trauma pada masyarakat. Namun, secara positif psikologis masyarakat menjadi lebih peduli dan waspada terhadap adanya banjir bandang di masa yang mendatang. Kewaspadaan masyarakat perlu didukung dengan pengembangan sistem peringatan dini banjir bandang yang ada melalui sebuah inovasi dengan memanfaatkan teknologi. Salah satu teknologi yang dapat dimanfaatkan adalah teknologi pemrosesan citra digital / digital image processing, Pemrosesan citra digital memproses data yang ditangkap melalui alat optik untuk dianalisis berupa gerak objek yaitu level Tinggi Muka Air (TMA) permukaan air sungai yang menunjukan level tertentu dalam papan kontrol (Peil) yang terpasang di bendungan. Pengolahan citra digital adalah disiplin ilmu yang mempelajari pemrosesan citra menggunakan teknikteknik dalam mengolah citra. Citra yang dimaksud di sini adalah citra diam/stil images(misal: foto) atau citra bergerak/moving images yang merupakan rangkaian citra diam yang ditampilkan sekuensial menjadi sebuah frame (misal: video) [1].
Penelitian [2] mengembangkan purwarupa peringatan dini banjir menggunakan VoIP. Telemetri dibangun melalui sambungan telepon pada dua stasiun yaitu stasiun monitoring dan stasiun peringatan yang tidak dalam satu lokasi, untuk memberikan peringatan dini bencana banjir. Penelitian [3] dilakukan untuk mendeteksi objek bergerak berbasis tracking objek menggunakan metode Background Substraction dan Kalman Filter. Hasil yang didapat adalah gerak objek pada video dapat dideteksi oleh metode Background Substraction dan pergerakan objek dapat disetimasi dengan Kalman Filter. Penelitian lain yang dilakukan untuk mendeteksi gerak objek adalah penelitian [4] yang menggunakan Background Substraction dan teknik Frame Differencing mendeteksi gerakan. Hasil yang didapat adalah mampu mendeteksi gerakan yang terjadi, dengan memperhatikan nilai threshold dan perubahan cahaya pada objek yang bergerak.

Volume jumlah air yang meningkat pada sebuah Daerah Aliran Sungai (DAS) ataupun Bendungan, menjadi salah satu indikator adanya banjir, maka fokus penelitian ini adalah pada monitoring level ketinggian air dan deseminasi informasi yang dihasilkan sebagai peringatan dini kepada masyarakat. Deteksi level Tinggi Muka Air (TMA) dapat dilakukan dengan membandingkan level TMA sebagai objek model dengan papan penunjukan level TMA sebagai latar belakang (bakcground) 
sejalan dengan hasil pada penelitian [5], menerangkan bahwa background subtraction adalah teknik untuk menemukan objek pada gambar dengan cara membandingkan gambar yang ada dengan sebuah model latar belakang. Penelitian [6] menemukan bahwa IP Camera dapat mendeteksi warna merah dengan tingkat keberhasilan sebesar 97\% dan tingkat keberhasilan level yang ditunjukkan mencapai 95\%. Pada penelitian [7], menunjukan bahwa pelacakan level ketinggian air berdasarkan warna dengan background subtraction dapat dilakukan dengan memperhatikan beberapa parameter yaitu, jangkauan jarak dan sudut IP Camera terhadap papan ketinggian level air. Parameter lain yang berpengaruh adalah tingkat intensitas cahaya pada saat IP Camera menangkap objek.

Penelitian ini bertujuan untuk menguji pendeteksian level Tinggi Muka Air (TMA) pada papan skala penunjukkan ketinggian (Peil) telah menggunakan metode Background Subtraction pada kondisi nyata. Keluaran dari analisis ini yaitu parameter-parameter optimal dimana IP Camera dapat mendeteksi skala penunjukan level tinggi muka airt (TMA) pada papan Peil.

\section{METODOLOGI PENELITIAN}

Berdasarkan pada penelitian penelitian sebelumnya, maka pada penelitian ini, dilakukan pelacakan warna merah pada papan Penunjukan Tinggi Muka Air/ Papan TMA (Peil) menggunakan Deteksi Blob [8] dan metode Background Subtraction [9] untuk melacak level Tinggi Muka Air pada Papan Peil. Penggunaan kedua teknik ini dikombinasikan dengan penentuan nilai ambang batas (threshold) yang sudah ditentukan. Parameter-parameter lain yang berpengaruh antara lain Jarak dan Sudut $I P$ Camera terhadap skala penunjukkan level serta Intensitas Cahaya dan Ketinggian Posisi IP Camera.
p-ISSN : 2527-4856, e-ISSN : 2614-5413

https://journal.uniku.ac.id/index.php/buffer

\subsection{Perancangan Papan Tinggi Muka Air (Peil TMA) dan IP Camera}

TMA (Tinggi Muka Air ) menunjukan level ketinggian air yang dibagi menjadi 3 bagian yang mana masing masing bagian dengan tinggi $300 \mathrm{~cm}$. Setiap masing-masing bagian menunjukkan level dengan kondisi aman, waspada, dan bahaya. Pada analisis sistem akan melacak level ketinggian air, dengan ketentuan analisis:

1. Jika TMA masih berada pada bagian ke-1 dan maksimal menutupi 1 bagian dari bawah, maka status AMAN

2. Jika TMA masih berada pada bagian ke-2 dan maksimal menutupi 2 bagian dari bawah, maka status WASPADA

3. Jika TMA masih berada pada bagian ke-3 dan maksimal menutupi 3 bagian dari bawah, maka status BAHAYA

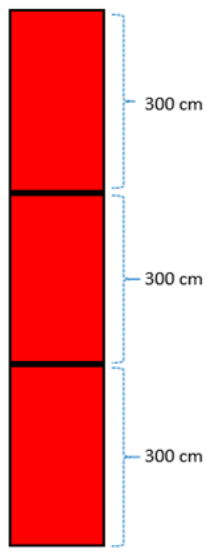

Gambar 1. Modifikasi Papan Tinggi Muka Air (TMA Peil) Leveling Warna Merah

Konfigurasi penempatan posisi IP kamera menentukan kemampuan dalam melacak Tinggi Muka Air (TMA). Parameter-parameter yang mempengaruhi antara Jarak dan Sudut IP Camera terhadap skala penunjukkan level serta Intensitas Cahaya dan Ketinggian Posisi IP Camera 


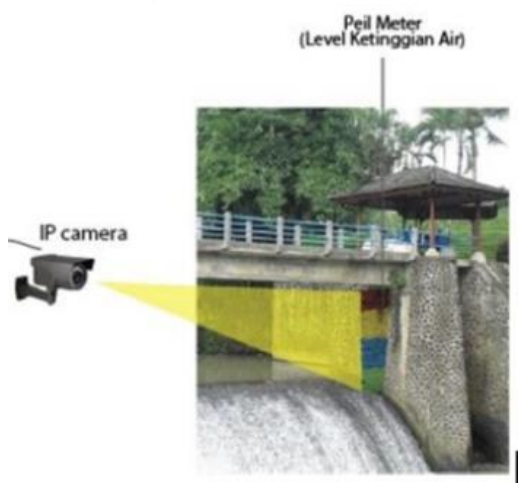

Gambar 2. Konfigurasi Penempatan IP Camera pada Bendungan

\subsection{Pelacakan Warna Merah Pada Papan Tinggi Muka Air (TMA Peil)}

Alur dari sistem analisis untuk melacak level ketinggian air dapat dilihat pada Gambar 3:

1. Menangkap Citra dari IP kamera. Perekaman objek dilakukan manual dengan resolusi IP kamera di setting terlebih dahulu

2. Pada citra video yang telah dibuat, maka dilakukan pelacakan skala penunjukkan warna merah.

3. Pada proses tracking color, tracking objek warna ini menggunakan deteksi blob [10] dimana mendeteksi kumpulan titik-titik pixel yang memiliki warna berbeda dari background dan menyatukannya dalam suatu region. Pada pelacakan level ketinggian air juga dilakukan teknik background substraction. Prosesnya dalam background susbtraction dengan melakukan pengurangan terhadap gambar saat ini dengan gambar sebelumnya.

4. Saat air pada Peil Tinggi Muka Air (TMA) yang ada di sungai tidak menutupi dan atau sampai menutupi 1 bagian merah dari Peil, menandakan bahwa kondisi masih normal/aman, tetapi ketika 1 bagian merah Peil telah tertutupi oleh air dan atau menuju 2 bagian maka kondisi dalam keadaan waspada. Lain halnya jika 2 bagian telah tertutupi air dan atau menuju 3 bagian, menunjukkan bahwa kondisi sudah bahaya sehingga harus dilakukan tindakan yang lebih lanjut kepada pihak pengambil keputusan

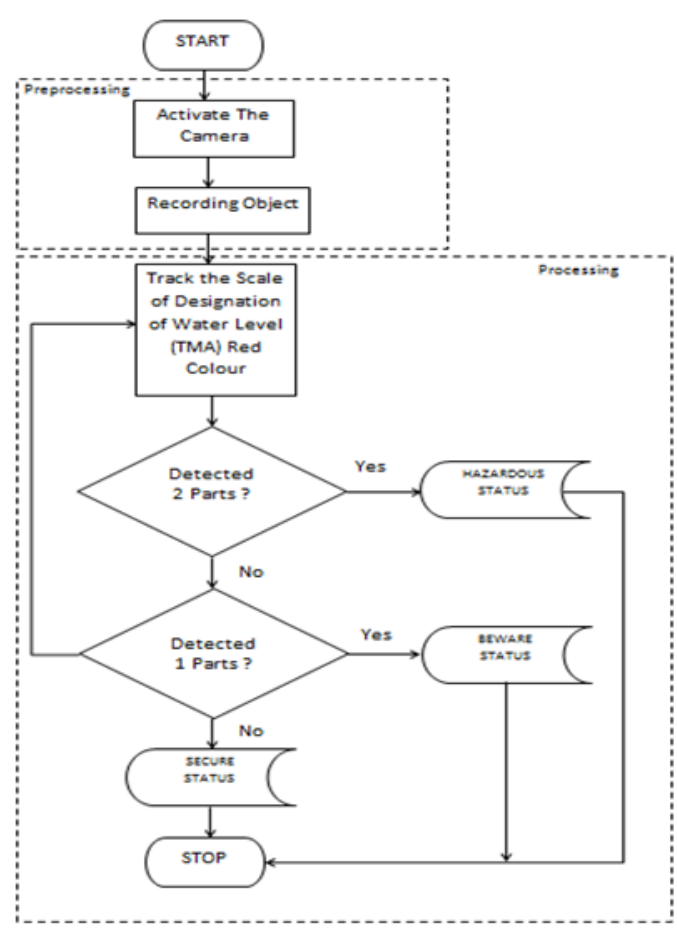

Gambar 3. . Alur Pelacakan Level Tinggi Muka Air pada Peil TMA Warna Merah

\section{HASIL DAN PEMBAHASAN}

\subsection{Pengujian Parameter Jarak dan Sudut IP Camera terhadap Peil TMA}

Pengukuran jarak jangkauan dan sudut juga diujikan untuk mendapatkan jarak jangkauan dan sudut minimum dan jarak jangkauan dan sudut maksimum. Jarak jangkauan dan sudut minimum adalah jarak ambang terdekat IP kamera masih dapat mendeteksi skala penunjukkan 
dan jarak jangkauan dan sudut maksimum merupakan jarak terjauh dan sudut maksimum dimana IP kamera tidak dapat mendeteksi skala penunjukan level ketinggian

Pengujian pertama berupa pengujian jarak minimum IP kamera. Adapun langkah-langkah pengujian pencarian jarak minimum, yaitu:

- Mengarahkan IP kamera ke skala penunjukan level ketinggian air.

- Posisi IP kamera digerakkan mendekati ke skala penunjukan level ketinggian hingga jarak minimum.

- Kemudian dianalisis pada Matlab yang telah dibuat programnya terlebih dahulu.

- Proses ini dilakukan sebanyak 20x

Dari pengujian pencarian jarak minimum pengenalan penanda TMA pada Peil didapatkan jarak minimum yaitu $200 \mathrm{~cm}(2 \mathrm{~m})$. Pengujian jarak maksimum IP kamera terhadap skala penunjukan level ketinggian air dilakukan dengan menggerakkan IP kamera menjauh dari skala penunjukan dan dilakukan berulang kali sebanyak 20x. Jarak maksimum yang didapat dari pengujian ini yaitu sebesar $600 \mathrm{~cm}(6 \mathrm{~m})$

Jarak jangkauan dan sudut berdasarkan identifikasi pengenalan IP kamera terhadap skala penunjukan terdapat pada Gambar Jarak IP Kamera dan Gambar Sudut IP Kamera. Jarak jangkauan IP kamera terhadap skala TMA Peil yang kurang dari $200 \mathrm{~cm}$ dan lebih dari $600 \mathrm{~cm}$ merupakan jarak jangkauan IP kamera tidak dapat melakukan pelacakan ketinggian level ketinggian air, sedangkan untuk sudut yang digunakan adalah 15, 30, 45 dan 60 derajat. Pada jarak $200 \mathrm{~cm}$ dengan sudut 30, 45, dan 60 derajat, skala TMA Peil dapat terdeteksi dan dapat dianalisis, pada jarak $400 \mathrm{~cm}$ sudut yang dapat terdeteksi dan terlacak adalah 45 dan 60 derajat, jarak $600 \mathrm{~cm}$ sudut yang terdeteksi dan terlacak hanya 60 derajat, tetapi pada jarak 800 $\mathrm{cm}$ sudut tidak terdeteksi dan terlacak

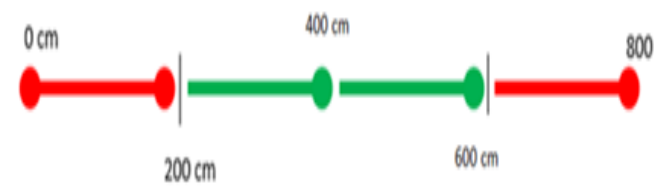

Gambar 4. Gambar Optimal Jarak Penempatan IP Camera terhadap Peil TMA

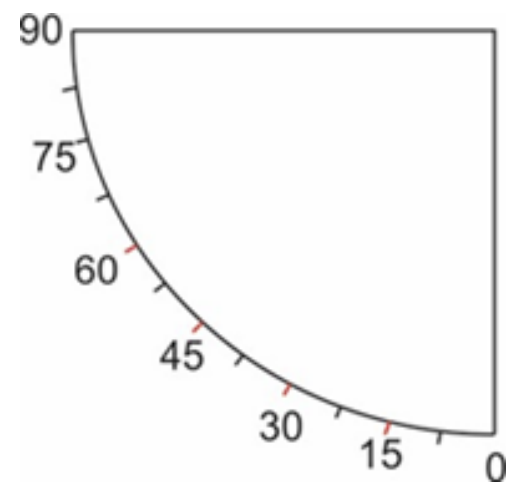

Gambar 5. Kisaran Sudut IP Camera terhadap Peil TMA

Hasil Pengujian jarak IP kamera dan sudut dapat dilihat pada Tabel 1 dibawah ini:

\begin{tabular}{|r|r|r|r|r|}
\hline \multirow{2}{*}{ Sudu } & \multicolumn{4}{|c|}{ Jarak $(\mathrm{Cm})$} \\
\cline { 2 - 5 } $\mathrm{t}\left({ }^{\circ}\right)$ & 20 & 40 & 60 & 800 \\
& 0 & 0 & 0 & \\
\hline 15 & $\times$ & $\times$ & $\times$ & $\times$ \\
\hline 30 & $\sqrt{ }$ & $\times$ & $\times$ & $\times$ \\
\hline 45 & $\sqrt{ }$ & $\sqrt{ }$ & $\times$ & $\times$ \\
\hline 60 & $\sqrt{ }$ & $\sqrt{ }$ & $\sqrt{ }$ & $\times$ \\
\hline
\end{tabular}

Keterangan: $\sqrt{ }=$ Terdeteksi, $\mathbf{X}=$ Tidak Terdeteksi

\subsection{Pengujian Parameter Intensitas Cahaya dan Ketinggian IP Camera terhadap Peil TMA}

Pengujian ketinggian IP kamera dan intensitas cahaya dilakukan bervariasi, untuk mengetahui pengaruh dari penempatan posisi yang tepat terhadap intensitas cahaya. Pengujian posisi penempatan IP kamera dilakukan dengan membagi 
ketinggian posisi IP kamera menjadi dua level ketinggian, yaitu:

a. Level Rendah adalah level ketinggian posisi IP Kamera dimana IP kamera dapat mendeteksi dan melacak skala TMA Peil

b. Level Tinggi. Adalah level ketinggian posisi IP Kamera dimana IP Kamera sulit mendeteksi dan melacak skala TMA Peil, sehingga analisis menunjukan tidak dapat mendeteksinya

Pada penelitian ini, posisi ketinggian IP kamera di batasi dengan ketinggian 1000-1500 cm (10 - 15 meter) sedangkan intensitas cahaya dibatasi antara 500-2000 lux. Hasil pengujian ketinggian posisi IP kamera dan intensitas cahaya ditunjukkan pada Tabel 2. Jika ketinggian IP kamera dengan intensitas cahaya yang cukup, maka analisis dalam mendeteksi dan melacak skala penunjukkan ketinggian air dapat dilakukan. Level ketinggian posisi IP kamera lebih dari $1250 \mathrm{~cm}$ merupakan level tinggi sehingga analisis Skala TMA Peil sulit didapatkan, dikarenakan ukuran skala penunjukan menjadi kecil dan area warna juga sulit ditangkap oleh IP kamera. Maka, level ketinggian posisi IP Kamera dari $1150-1250 \mathrm{~cm}$ merupakan area yang dapat ditangkap oleh IP kamera secara penuh sehingga dalam mendeteksi dan melakukan pelacakan dapat dilakukan dengan baik.
p-ISSN : 2527-4856, e-ISSN : 2614-5413

https://journal.uniku.ac.id/index.php/buffer

Tabel 2. Hasil Pengukuran Intensitas

Cahaya dan Tinggi IP Kamera terhadap TMA Peil

\begin{tabular}{|c|c|c|c|c|c|c|c|}
\hline \multirow{2}{*}{$\begin{array}{c}\text { Tinggi } \\
(\mathrm{cm})\end{array}$} & \multicolumn{7}{|c|}{ Intensitas Cahaya (lux) } \\
\cline { 2 - 8 } & 786 & 1263 & 1193 & 1386 & 1695 & 1750 & 1980 \\
\hline 1000 & $\times$ & $\sqrt{ }$ & $\times$ & $\times$ & $\times$ & $\times$ & $\times$ \\
\hline 1050 & $\times$ & $\times$ & $\times$ & $\sqrt{ }$ & $\times$ & $\times$ & $\times$ \\
\hline 1100 & $\times$ & $\times$ & $\times$ & $\times$ & $\times$ & $\sqrt{ }$ & $\times$ \\
\hline 1150 & $\sqrt{ }$ & $\sqrt{ }$ & $\sqrt{ }$ & $\sqrt{ }$ & $\sqrt{ }$ & $\sqrt{ }$ & $\sqrt{ }$ \\
\hline 1200 & $\sqrt{ }$ & $\sqrt{ }$ & $\sqrt{ }$ & $\sqrt{ }$ & $\sqrt{ }$ & $\sqrt{ }$ & $\sqrt{ }$ \\
\hline 1250 & $\sqrt{ }$ & $\sqrt{ }$ & $\sqrt{ }$ & $\sqrt{ }$ & $\sqrt{ }$ & $\sqrt{ }$ & $\sqrt{ }$ \\
\hline 1300 & $\times$ & $\times$ & $\times$ & $\times$ & $\times$ & $\times$ & $\times$ \\
\hline 1350 & $\times$ & $\times$ & $\times$ & $\times$ & $\times$ & $\times$ & $\times$ \\
\hline 1400 & $\times$ & $\times$ & $\times$ & $\times$ & $\times$ & $\times$ & $\times$ \\
\hline 1450 & $\times$ & $\times$ & $\times$ & $\times$ & $\times$ & $\times$ & $\times$ \\
\hline 1500 & $\times$ & $\times$ & $\times$ & $\times$ & $\times$ & $\times$ & $\times$ \\
\hline
\end{tabular}

Keterangan: $\sqrt{ }=$ Terdeteksi, $\mathbf{x}=$ Tidak Terdeteksi

Pada Gambar Ketinggian IP Kamera menunjukkan posisi ketinggian IP kamera pada ketinggian ini dapat dibagi tiga level ketinggian, dimana pada warna hijau merupakan level deteksi. Posisi level deteksi ini adalah posisi yang optimal dalam menempatkan posisi IP kamera, sehingga skala penunjukan secara penuh terdeteksi dan terlacak. Sedangkan warna merah merupakan level deteksi non Optimal, posisi pada level ini IP kamera dapat menangkap skala penunjukan akan tetapi pada saat dianalisis tidak dapat mendeteksi dan melacak skala penunjukkan sehingga level ini adalah posisi yang tidak optimal dalam menempatkan IP kamera. Warna hitam adalah posisi ketinggian diluar jangkauan IP Kamera, dimana IP kamera tidak dapat menangkan seluruh skala penunjukan pada Skala TMA Peil 


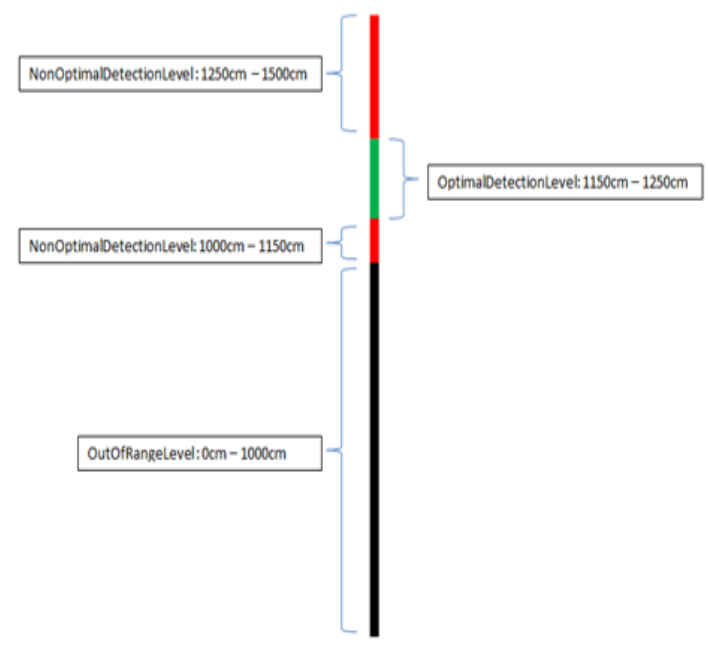

Gambar 5. Tinggi Optimal IP Camera terhadap Peil TMA

\section{KESIMPULAN}

Hasil dari pengujian pada lokasi menunjukan jarak jangkauan optimal $I P$ Camera dan sudut IP Camera yang masih dapat mendeteksi penunjukan skala pada Peil TMA yaitu pada jarak $200 \mathrm{~cm}$ sampai jarak $600 \mathrm{~cm}$ dengan sudut 30, 45, dan 60 derajat, Sedangkan pengujian ketinggian IP Camera dan intensitas cahaya menunjukan level ketinggian posisi IP Camera dari 1150 - $1250 \mathrm{~cm}$ pada intensitas cahaya 786 - 1980 Lux, merupakan area yang dapat ditangkap oleh IP kamera secara penuh sehingga dalam mendeteksi dan melakukan pelacakan dapat dilakukan dengan baik.

\section{DAFTAR PUSTAKA}

[1] Rinaldi Munir, Pengolahan Citra Digital dengan Pendekatan Algoritmik, Informatika, Bandung. 2004

[2] M. Ulfiyanto and I. L. E. Nugroho, "PENGEMBANGAN PROTOTIPE VOIP UNTUK TELEMETRI SISTEM PERINGATAN DINI BANJIR," Universitas Gadjah Mada, 2012.

[3] N. R. B.S.L and D. F. Akbar, "Object Tracking Berbasis Background Substraction dan Kalman Filter " 2014

[4] K. D. Irianto and G. Ariyanto, "MOTION DETECTION USING OPENCV WITH
p-ISSN : 2527-4856, e-ISSN : 2614-5413

https://journal.uniku.ac.id/index.php/buffer
BACKGROUND SUBTRACTION AND FRAME DIFFERENCING TECHNIQUE," 2009

[5] E. Ardhianto, W. Hadikurniawati, and Z. Budiarso, "Implementasi Metode Image Subtracting dan Metode Regionprops untuk Mendeteksi Jumlah Objek Berwarna RGB pada File Video," Dinamik-Jurnal Teknologi Informasi, vol. 18, 2013.

[6] Kurniawan, A. Mustika, IW dan Kusumawardani, SS. "Pengujian Tracking Color Menggunakan IP Webcam Untuk Deteksi Ketinggian Air”. 2014

[7] Kurniawan, A. Mustika, IW dan Kusumawardani, SS, "Pelacakan Level Ketinggian Air Berdasarkan Warna dan Background Substraction”. 2014

[8] M.Piccardi(2004). "Background Substraction Techniques : a review”, IEEE International Conference on Systems, man and Cybernetics(IEEE Cat. No. 04CH37583) The Hague Netherland 2004.

[9] Sebastian Brutzer,Benjamin Höferlin, Gunther Heidemann (2011).’Evaluation of background Subtaction technique for Video Surveillance" IEEE Xplore: 22 August 2011. DOI: 10.1109/CVPR.2011.5995508. Colorado Springs, CO, USA, USA

[10] Choirul Ridho Nurhuda, Kartika Firdausy "METODE COLOR BLOB DETECTION UNTUK DETEKS KEMATANGAN TOMAT SECARA OTOMATIS BERBASIS ANDROID”. 2017 